\title{
MedienPädagogik
}

Zeitschrift für Theorie und Praxis der Medienbildung

Special Issue Nr. 35:

Media literacy as intergenerational project: skills, norms, and mediation

Edited by Claudia Riesmeyer, Thorsten Naab,

Anne-Linda Camerini, Ruth Festl, and Christine Dallmann

\section{The family rules. The influence of parenting styles on adolescents' media literacy}

Claudia Riesmeyer, Bernadette Abel, and Annika Großmann

\begin{abstract}
The paper examines the relationship between parenting styles concerning media and the ability of young people to criticize media. It is based on 28 qualitative interviews with each parent and their children. Young people use social networks such as Instagram extensively, while their parents use them much less often. Nevertheless, they are the first instance of media socialization. They should communicate norms for media use and inform about opportunities and risks. Instagram fulfils adolescents' desire for social interaction with others or participation in the life of others, documentation of everyday life and the possibility of self-expression through its visual characteristics. The paper develops a typology of young people depending on parenting styles and illustrates their relevance for media criticism. The dimensions of parenting styles heat and control characterize this ability. The higher the warmth of parenting, the higher the children's ability to criticize the media. The influence of control is less clear. It is advantageous to a certain degree and helps the children. If it becomes too strong, control unfolds a rather negative potential that inhibits young people's media literacy.
\end{abstract}

Die Familie zählt. Der Zusammenhang zwischen elterlicher Medienerziehung und Medienkritikfähigkeit Jugendlicher

\section{Zusammenfassung}

Der Aufsatz untersucht den Zusammenhang zwischen der elterlichen Medienerziehung und der Medienkritikfähigkeit Jugendlicher. Basis sind je 28 qualitative Interviews mit einem Elternteil und ihren Kindern. Jugendliche nutzen soziale Netzwerke wie Instagram extensiv, ihre Eltern hingegen deutlich seltener. Dennoch sind sie erste Instanz der Mediensozialisation. Sie sollen Normen für die Mediennutzung vermitteln und über Chancen und Risiken aufklären. Instagram erfüllt den Wunsch Jugendlicher nach der sozialen Interaktion mit anderen bzw. die Teilhabe am Leben anderer, die Dokumentation des alltäglichen Lebens sowie die Möglichkeit zum Selbstausdruck durch seine visuelle Charakteristik. Der Aufsatz erarbeitet eine Typologie der Jugendlichen in Abhängigkeit der Medienerziehung und verdeutlicht deren Relevanz für die Medienkritikfähigkeit. Die Dimensionen elterlicher (Medien)erziehung Wärme und Kontrolle prägen diese Fähigkeit. Je höher die 
Wärme der Erziehung, desto höher ist die Medienkritikfähigkeit der Kinder. Der Einfluss der Kontrolle ist weniger deutlich. Sie ist bis zu einem gewissen Grad vorteilhaft und hilft den Kindern. Wird sie zu stark, entfaltet die Kontrolle ein eher negatives Potenzial, das die Medienkompetenz Jugendlicher hemmt.

\section{Introduction}

Adolescents are «always and everywhere accessible» as well as «constantly connected to each other on the 'net» (Palfrey and Gasser 2008, 5; see also POPC, Vorderer et al. 2017). They use social media such as Instagram for posting, sharing, commenting, and connecting with peers. Half of all youths between the ages of 12 and 19 use Instagram regularly (JIM 2018). Given the platform's rapid increase in users, Instagram even "out-shadowed the growth of Facebook and Twitter» (Aßmann and Röbbeln 2013, 26), which exemplifies its importance in the social media realm. With its visual characteristics, Instagram seems to be designed for self-representation and for fulfilling adolescent's desire (according to their developmental tasks) for social interaction with others or participation in the life of others, documentation of everyday life and the possibility of self-expression through its visual characteristics (Havighurst 1972; Lee et al. 2015; Sheldon and Bryant 2016). Using social media platforms like Instagram, people classify and evaluate received content - skills that adolescents acquire during the media-socialization process. Various actors and groups are involved in this process, with parents playing a central role (Arnett 1995a, b; Süss 2004). The importance of parents in media education stems from the fact that the family remains the most important socialization place for adolescents (Albert et al. 2015; Arnett 2007; Belsky 1984; Hurrelmann and Bauer 2015, 2018). However, parents use social media much less often than their children and regularly have difficulty fully grasping this media world's complexities (Wagner and Gebel, 2014). In addition to different uses, parents' and children's personal characteristics influence the media socialization process (e.g., such as gender, age and socio-economic status, SES; Livingstone, Haddon, and Görzig 2012). Often parents struggle with the possibilities and risks social media platforms offer (Blum-Ross et al. 2018).

Nevertheless, parents have the task of creating an environment which provides the best circumstances for their children to acquire media literacy skills (e.g., for the social media use), as well as they have to accompanying the adolescents during their learning process. To meet this challenge parents must adapt their educational methods to the times to address the digital world's challenges and potential dangers. Furthermore, parents' demanding media-education task recently has expanded amid the progressive social processes of medialization (Wagner and Gebel 2014). The family atmosphere offers adolescents needed positive, emotional support on their way to adulthood, and this is an optimal growth stage when parents could help their 
children to learn how to use media appropriately, and set limits and regulations to their media use. Particularly because media increasingly penetrate areas of everyday life and open up new possibilities for interaction within the family, they hardly can be kept out of family life (Wagner and Gebel 2014). Socialization takes place in the family context through different parenting styles, which is, according to Maccoby and Martin (1983), is a process that happens somewhere between the dimensions of warmth and control and can be differentiated through the educational measures used (Parental Mediation Theory, Clark 2011; Jiow, Lim, and Lin 2017; Peterson and Hann 1999). One aim of parental education and socialization of adolescents is the acquisition of media literacy, which unfolds within the context of family and its inherent media activities. How can the connection between parenting strategies concerning media and adolescents' media literacy best be characterized?

This paper focuses on the ability to reflect media content critically, i.e., evaluative media literacy, and on the social network Instagram. Based on qualitative interviews with parents and their children, this research presents a typology of adolescents' evaluative media literacy depending on the parenting style.

\section{Theoretical background: Media socialization within families}

Socialization aims to shape an individual into a socially capable subject (Hurrelmann 1990; Wagner 2011, 2013a) who is a morally upright member of society (Bachmair 2006; Lüscher and Liegle 2015). It is a process in which «individuals are assisted in the acquisition of skills necessary to function as members of their group» (Grusec 2002, 143). These individuals learn to regulate emotions, thoughts, and behaviors; to acquire cultural values and norms for integration into society; to resolve conflicts; to evaluate social relationships; and to take on active roles. In this process not only the result counts, but also the "genesis of skills for social action» (Wagner 2013a, 273), which also takes place on the adaptation of media content.

Part of this socialization process entails the acquisition of skills and the mediation of norms for media use, «the media are integrated in a variety of ways into the everyday lives of individuals and their actions» (Wagner 2013a, 276). This process takes place through self-socialization and external socialization (Arnett 1995a, b, 2007; Süss 2010). Self-socialization emphasizes the individual's active role in the socialization process and comprises self-directed media and content choices, as well as a biased reception in which one's own developmental tasks and everyday references serve as orientation (e.g., media appropriation, Wagner 2013a). External socialization focuses on the role of external instances in the media-socialization process (e.g., family, teachers, peers). These instances and adolescents' socialization goals determine how they deal with the media (Süss 2010). According to Hurrelmann and Bauer $(2015,2018)$, the family is the most important and primary socialization instance, 
communicating external reality to adolescents and helping them filter and interpret it. In addition, the family, as youths' first conduit with media, provides impulses to create inner reality. Parental socialization, along with that of others, can be deemed media education. However, it depends on the general education concept (Süss 2010).

\section{Parenting Styles}

Pedagogical approach, which determines how parents raise their children, representing a «pattern of parental behavior and attitudes in the upbringing of [the] children» (Walper, Langmeyer, and Wendt 2015, 369). Following Maccoby and Martin (1983) distinctions between parenting styles are made based on the warmth and control dimensions. Originating from the discipline of child psychology, this categorization belongs to the most pervasive concepts within education. Warmth is used synonymously in extant literature with acceptance, love, or support (Weber 2015) and refers to parents' affection for their children. However, control includes «the regulation of childlike behavior or (...) the behavior of parents who are supposed to modify childlike behavior or the formation of the 'inner state' (attitudes, values ...)» (Peterson and Hann 1999, 333). Following Maccoby and Martin (1983), four parenting styles result from these dimensions:

- Authoritative-democratic: Characterized by high warmth levels and clear rules. These parents usually communicate openly with their children, discuss rules, and reach compromises. They view their children's independence as important, although they take responsibility for their children's actions, thereby creating a safe environment in which adolescents have the opportunity for self-socialization. To maintain the balance between autonomy and restriction, these adolescents are granted more freedom with increasing age (Seel and Hanke 2015).

- Negligent: Characterized by low warmth levels and little control. These parents minimize time and effort in interacting with their children and act partially oblivious. They know neither about their children's whereabouts nor about their activities and attach little importance to their opinions (Seel and Hanke 2015).

- Authoritative: Characterized by pronounced control and medium to low warmth levels. These parents attach great importance to obedience and conformity. Through strong control, they limit their children's independence, thereby preventing the development of independence and consciousness (Gugel, Ritzi, and Heuss 2013).

- Permissive: Characterized by high warmth levels and little control. These parents grant their children a great degree of freedom in connection with few behavioral requirements. Therefore, this style can be described as pampering (Walper et al. 2015). Active steering of the child takes place to a very limited extent. Rather, parents see themselves as a resource that their children can turn to when needed (Seel and Hanke 2015). 
A broad consensus exists that the authoritative-democratic educational style creates the best conditions for positive development of adolescents, while the negligent style is considered the most negative. Permissive and authoritarian styles move between the two extremes, with the permissive style seeming to exert rather positive effects on children's development (Seel and Hanke 2015).

The four parenting styles also can be distinguished with regard to parenting styles concerning media education. The focus here is on whether parents control their children's media use, define rules, or create freedom and to what extent they support them.

\section{Parental mediation}

Parental mediation theory's starting point is parental media education on childhood TV consumption (Nathanson 1999, 2001; Valkenburg et al. 1999). A distinction is made between three forms of parental mediation (Lemish 2015):

- Restrictive measures include rules and regulations that parents institute, including sanctions for non-compliance (Nathanson 2004, 2010; Mares et al. 2018).

- Active measures rely on parent-child discussions to interpret and classify media content (Gentile et al. 2012; Warren 2001).

- Accompanying measures are sometimes referred to as co-using and refer to parents and children's common use of media (Clark 2011; Mendoza 2009).

Those measures are educative decisions and practices by the parents. According to Jiow et al. (2017), these three measures serve as overarching strategies differentiated by four further dimensions - gatekeeping, discursive, investigative, and distracting dimensions - and are applied in various combinations. For example, restrictiveinvestigative measures serve to determine the extent to which established rules are followed. Active-investigative measures are used to provide parents with discussion topics, thereby promoting dialogue with their children. With the help of these differentiations, the degree of parental control can be determined. For example, particularly restrictive gatekeeping measures indicate a high level of control, while activediscourse measures indicate moderate control and are an important prerequisite for a relationship at their children's level, in which media communication is a mediasocialization task.

\section{Evaluative media literacy}

Media literacy is regarded as a key qualification for «finding one's way around and acting in a media-influenced world» (Aufenanger 2006, 118; Groeben 2004; Potter 2010). A media-literate individual acts media-responsible (Lampert 2006). Media literacy 
is essential for sovereign, independent, and socially responsible handling of media (Sowka et al. 2015), and it is normatively perceived as an objective. Schorb (2005) defines media literacy as a learnable bundle of partial skills, such as media knowledge, media action, and media evaluation, whereas this paper is limited to media evaluation only, which is viewed as a central dimension of media literacy (Sowka et al. 2015). Developing young people into responsible individuals requires approaching media critically and reflectively. Therefore, the ability to review the media is an often-discussed dimension of media literacy (Lemish 2015).

These skills are important in processing inner and outer realities. On the basis of the evaluation of previous environmental incidents and experiences, recipients are enabled to «orient and structure their own actions in a targeted manner» (Hurrelmann and Bauer 2015, 149). This discussion leads to an individual action guideline to interpret and evaluate media (content). Media evaluation consists of six dimensions (Sowka et al. 2015; Treumann et al. 2007):

1. Analytical dimension: Recognition of staging (fictional vs. non-fictional media content). Analytical skills help ensure that the recipient's thinking, feeling, and acting are based on realistic world assessments (Potter 2013).

2. Reflexive dimension: Recognition of intentionality, which is closely linked to the analytical dimension. The recipient who is capable of criticism should recognize intentions that are not openly communicated and pursued in connection with media content (e.g., commercial interests behind advertising messages).

3. Credibility: Assessment of the message's reliability and classification, e.g., regarding commercial or non-commercial intentions. A self-determined formation of opinion and life function is made possible through a truthful picture of reality (Rozendaal et al. 2011). In this respect, the second and third dimensions are related directly to each other. Only recognizing communication intention enables the recipient to assess senders critically regarding their credibility.

4. Reflection of personal media use: Focusing on one's own media use and critically examining it. This dimension focuses not only on communication outlets, but also on one's own media use. It includes «[...] the ability of young people to make themselves and their media activities the object of analysis» (Treumann et al. 2007, 33). This requires that a balance be struck between one's own aspirations and the (normative) demands placed on appropriate forms of media representation.

5. Ethical dimension: Moral critical evaluation that considers human dignity, part of the self-revelation of personal value standards. It is decisive to what extent «[...] young people can make value judgments about media and their contents» (Treumann et al. 2007, 33). For example, this is expressed by whether the social consequences of media content are factored into the judgments. 
6. Recognition of threats and opportunities: Connections between inner and outer realities. Which chances/risks are connected with one's own and others' media use? Awareness of danger increasingly is expressed, e.g., whether the reflected recipient protects his or her privacy on social media and how attentive he or she is when dealing with external data.

Youths' individual ability to criticize media influences behavioral patterns, experiences in the online world, and perceptions of online dangers and opportunities. If one combines this with the fact that media evaluation is a decisive prerequisite for acquiring individual guidelines for action, the ability to criticize media is of central importance. As a core element of media evaluation, it is an indicator of young people's media literacy.

However, how do young people know how to use media literately and evaluate them critically? Teaching these skills is a central task in the media-socialization process and is taught through various agents, including parents - the most important socialization agent. This paper contextualizes extant research on parents' socialization and upbringing in the context of youths' media education and literacy development. Particular attention is paid to the extent to which the warmth and control dimensions - which are regarded as decisive parenting style characteristics - are related to adolescents' media literacy. The research question is:

$R Q$ : What is the relationship between parenting style and youths' media literacy in terms of assessment and reflection?

\section{Method: Qualitative interviews with parents and adolescents}

\section{Research design and interview guidelines}

To answer the research question, we conducted 28 qualitative interviews with parents and their children in summer 2018 (interview dyads). In addition, parents and adolescents were given a primary task (think aloud). Two printed Instagram images were presented, showing the extent to which parents and adolescents can reflect other people's - in the case of adolescents, their own - self-representation, the importance they would attach to it, and the evaluation of such content. The shown pictures differed in the staging of the representation. A picture was consciously chosen as a staged representation of a young woman showing an advertising cooperation with a cosmetics manufacturer. The other picture showed a young woman after sports or a young man in nature (depending on gender, the picture of the woman or the man was shown). All pictures were real representations of public profiles on Instagram. 
Qualitative interviews were chosen because this methodological design is wellsuited for examining attitudes, opinions, and behaviors, and because relevant aspects of media literacy and parenting styles are hardly observable. Thus, letting the "test objects" themselves talk about their experiences and specific world views helps make information relevant to research accessible (Vogl 2012). By means of these guidelines, the course of conversation is structured throughout the interview, and a basis of comparison for the interviewees is established. However, as this approach is only half-structured, enough space remains available for open-ended questioning (Keuneke 2017). Regarding the rising trend toward visual realms on social media sites, which led to the rise of platforms like Instagram (Faßmann and Moss 2016), the qualitative approach was applied on the latter.

We developed different interview guidelines for adolescents and parents, but they contained the same constructs. Both focused on adolescents' media use and literacy. Following the theoretical assumptions, the guidelines contained dimensions of evaluative media literacy that were realized as the ability to recognize and reflect other people's self-representation, as well as the importance that they would attach to it. Furthermore, interviewees were asked to reflect on the consequences of their actions, how they value the risks and benefits of Instagram, and how they evaluate others' actions. We included questions on everyday life as well, concerning the relationship between parents and children. To detect parenting styles, the adults also were asked how they mediate values, which rules and restrictions they establish concerning media, and what kind of expectations they place on their children's media use. All parts corresponded with the guidelines; therefore, the whole interview had to be analyzed. The interviews were conducted face-to-face, recorded, and transcribed into written form.

\section{Sample}

To understand the link between parenting styles and adolescents' evaluative media literacy, interview dyads with fathers or mothers and their children were conducted to gain a valid impression of the respective situation. Due to this conceptualization, the statements that each interviewee made can be put into perspective to reduce subjectivity. Most of the interviews took place at respondents' homes and lasted 21 to 28 minutes each. The dyads were recruited through personal contacts. In total, 18 girls, 10 boys, three men, and 25 women were interviewed. Ages varied from 14 to 17 and from 40 to 55 years (see table 1). Using a personal Instagram account and being between 14 and 17 years old occasionally was viewed as a basic requirement for the interviewed children because this age group makes particularly intensive use of Instagram (JIM 2018). Other recruitment criteria (e.g. with regard to education or the SES) were not defined for young people. Conversely, the parents did not have 
any restrictions concerning their participation on Instagram. For privacy matters, all respondents were given pseudonyms.

\begin{tabular}{|c|c|c|c|c|c|c|c|}
\hline \multicolumn{4}{|l|}{ Adolescents } & \multicolumn{4}{|l|}{ Parents } \\
\hline Pseudonym & Age & Sex & Education status & Pseudonym & Age & Sex & Education status \\
\hline Anton & 16 & $\mathrm{~m}$ & High school & Anna & 55 & $f$ & University \\
\hline Bea & 14 & $f$ & $\begin{array}{l}\text { Secondary modern } \\
\text { school }\end{array}$ & Beate & 49 & $f$ & Secondary school \\
\hline Cora & 15 & $f$ & High school & Carmen & 53 & $f$ & High school \\
\hline Diana & 15 & $f$ & High school & Dagmar & 42 & $f$ & Secondary school \\
\hline Elena & 16 & $f$ & Technical college & Eva & 46 & $f$ & Apprenticeship \\
\hline Franziska & 15 & $f$ & Secondary school & Fiona & 47 & $f$ & Apprenticeship \\
\hline Bastian & 16 & $\mathrm{~m}$ & High school & Gina & 54 & $f$ & Unknown \\
\hline Carsten & 15 & $\mathrm{~m}$ & Secondary school & Heidi & 51 & $f$ & University \\
\hline Daniel & 15 & $\mathrm{~m}$ & Secondary school & Inge & 49 & $f$ & University \\
\hline Nils & 16 & $\mathrm{~m}$ & High school & Judith & 51 & $f$ & Apprenticeship \\
\hline Gloria & 17 & $f$ & Secondary school & Kerstin & 47 & $f$ & Apprenticeship \\
\hline Hannah & 16 & $f$ & Secondary school & Lydia & 48 & $f$ & University \\
\hline Ina & 15 & $f$ & Secondary school & Maya & 48 & $f$ & High school \\
\hline Felix & 15 & $\mathrm{~m}$ & High school & Nora & & $f$ & University \\
\hline Gustav & 17 & $\mathrm{~m}$ & High school & Olga & & $f$ & Unknown \\
\hline Jana & 15 & $f$ & Secondary school & Pia & 50 & $f$ & University \\
\hline Klara & 16 & $f$ & Technical college & Albert & 49 & $\mathrm{~m}$ & University \\
\hline Lilli & 14 & $f$ & Unknown & Ruth & 50 & $f$ & University \\
\hline Mia & 15 & $f$ & High school & Sabine & 40 & $f$ & Unknown \\
\hline Nina & 14 & $f$ & Secondary school & Thea & 49 & $f$ & University \\
\hline Olivia & 17 & $f$ & High school & Boris & 48 & $\mathrm{~m}$ & University \\
\hline Paula & 17 & $f$ & High school & Ulrike & 45 & $f$ & Apprenticeship \\
\hline Henry & 17 & $\mathrm{~m}$ & Secondary school & Christian & 51 & $\mathrm{~m}$ & Apprenticeship \\
\hline Ilias & 16 & $\mathrm{~m}$ & High school & Vera & 45 & $f$ & Apprenticeship \\
\hline Rosa & 16 & $f$ & High school & Waltraud & 51 & $f$ & University \\
\hline Jonas & 16 & $\mathrm{~m}$ & Secondary school & Agathe & 43 & $f$ & Secondary school \\
\hline Steffi & 14 & $f$ & High school & Chiara & 53 & $f$ & University \\
\hline Tina & 14 & $f$ & Secondary school & Doris & 44 & $f$ & University \\
\hline
\end{tabular}

Tab. 1.: Sample characteristics.

\section{Analysis}

All interviews were analyzed following a theory-driven approach (Meyen et al. 2019). The theoretical constructs named above were adapted and partly redefined, leading to the final category system. The categories turned out to be suitable for grasping similarities and differences between types (Kluge 2000). The first category is evaluative media literacy, i.e., the ability to reflect on media content critically. This skill comprises the six aforementioned dimensions: the analytical, reflexive, and ethical 
dimensions; assessment of credibility; critical reflection of personal media use; and recognition of threats and opportunities. For simplification purposes, this category will be called "evaluative media literacy" henceforth. The second category, parenting styles, focused on control in the sense of prohibitions and restrictions, as well as warmth manifested through the respective parent-child relationship (Wagner 2013b). Other indicators concerning the extent of warmth included interest that parents show in their children's lives, including their knowledge of life's realities and their children's emotional world, and the importance that they attach to mutual activities. As control and warmth build the main axes of our typology and a simple derivation from their linguistic meaning would have been too blurry, we integrated different "activities", deriving from the Parental Mediation Theory, in our approach. Those - here termed - measures were, therefore, used as a means to make our main indicators measurable. Generally, restrictive measures were seen as a sign for control, whereas active and accompanying measures mostly stood for a warm parenting style. Moreover, the rough distinctions of warmth and control - from low to high used by Maccoby and Martin (1983), turned out to be too undifferentiated. That's why their theory only functioned as a framework and was further established due to this research. Accordingly, there might be deviations from theory regarding parenting styles in this paper. The third category considers the personality of each individual interviewee. To get an exact idea of something so complex, everyday life and media use, as well as (the conformity between) the values of parents and children, were among the principal focus points. This category is highly important for the final classification and interpretation of the findings.

The analysis was conducted based on these three categories. First, the interviews were examined with a view towards the given categories, so that only crucial areas in the responses were marked and paraphrased. Then the comments containing research-related information were organized into a table in which direct comparisons of extracted aspects of the two interviews per dyad were made. To generalize this information and make it comparable, two more compression steps were taken with the aim of condensing the material and thus recognizing similarities and differences between the dyads (Meyen et al. 2019). In the last step, the second category was broken down into the extent of warmth and control. Additionally, the individual dimensions of media literacy were portrayed briefly and supplied with a positive or negative sign. Along with the different steps, the coders exchanged their initial dyads to guarantee the findings' comparability.

Based on the interview compressions, the dyads were assigned to the parenting styles outlined before. Because the line between an authoritative-democratic and a permissive parenting style is quite blurry, the dyads were incorporated into a table with four fields containing the axes «warmth» and «control». For means of precision, the latter dimensions were specified due to a continuum reaching from small to large 
extent. Thus, in the first step, the compressed information was used to locate the parenting style that the respective children experienced, referencing the extent of warmth and control. In the second step, the resulting point then was transformed into a cross. By using different-size crosses (conveying very low to very high), media literacy - as the third factor - could be integrated into the image. Thus, in the overall view, several agglomerations became apparent. The parenting styles (indicated through the extent of warmth and control) were linked directly to adolescents' media literacy. Finally, this led to four cohorts that turned out to be suitable for meeting the objectives for a typology: high internal homogeneity within the type and high external heterogeneity compared with other types (Kluge 2000). Based on that, the following process focused on analyzing the dyads' similarities within different cohorts, building the basis for the four characteristics in the following results section. The most striking characteristic in each type eventually reflects the type name (see figure 1).

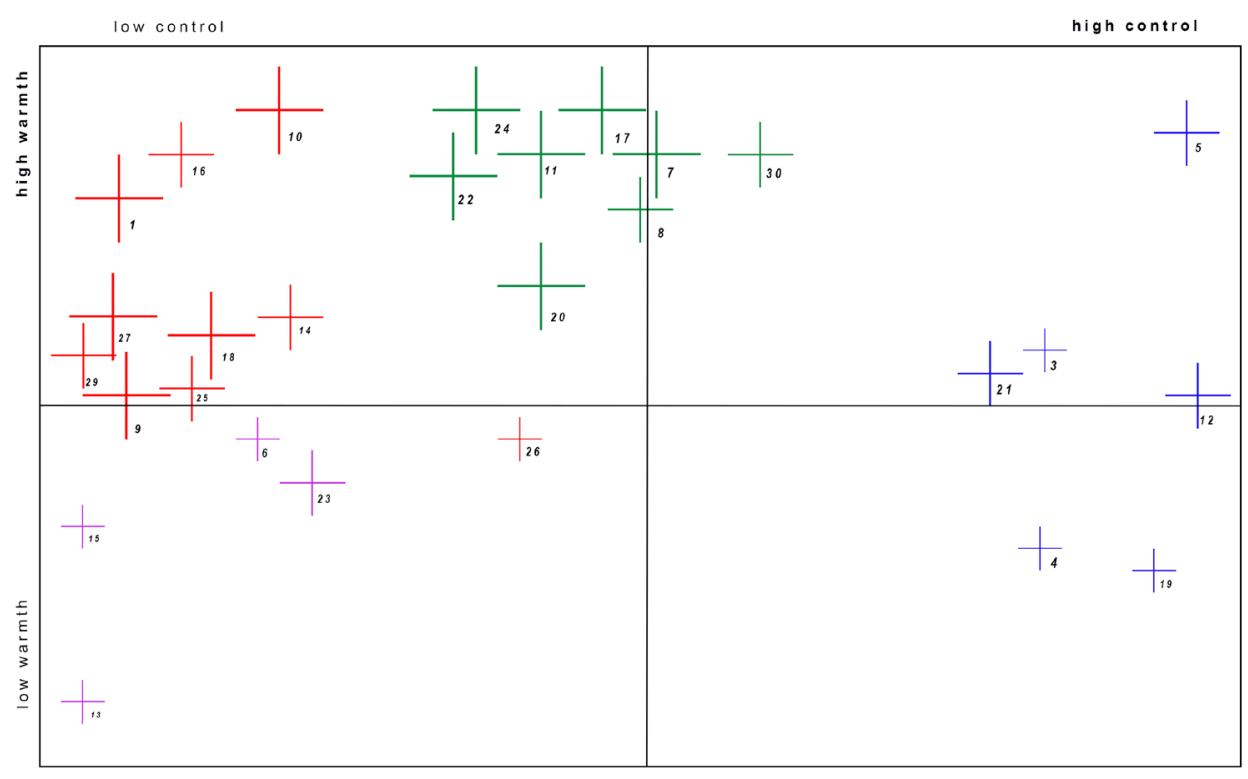

Fig. 1.: Development of types. ${ }^{1}$

\footnotetext{
1 + Type I: Reflected self-presenters

+ Type II: Authentic free spirits

+ Type III: Hazard-aware poseurs

+ Type IV: Transfigured imitators
} 
Results: Typology of adolescents based on their evaluative media literacy - combined with parenting styles

The typology evolves around the evaluative media literacy of adolescents. To give a holistic image of how this competence is composed, the parenting styles that children experience - as main indicator - are being taken into account. Thus, the following type descriptions do not solely focus on the characterizing features of the evaluative media literacy, but also stress the respective parenting style.

\section{Type I: Reflected self-presenters}

The first type is characterized by high evaluative media literacy on the one hand and authoritative parenting style on the other. This style of parenting - underlying Type I - comprises high warmth in combination with low to moderate control. Instead, parents' objective is to pose as a dialogue partner rather than control their children explicitly. To achieve this, mostly active-discursive activities are used.

«What we always talk about are the risks, of course. I think it's important to talk about it, basically that I, as an adult, can sharpen her awareness for them and see how much she can handle by herself. Of course, I supervise that» (Pia, parent).

Parents also demonstrate very strong interest in their children's social media activities and use a variety of investigative measures. This interest, in combination with low control, comprises a positive relationship between parents and children, one that adults describe as dialogue-based and characterize as mutual trust: «Because we have a two-way trust, I think I know what she's doing in the virtual realm. I don't control her, but I know it anyway because she shows me often herself» (Fiona, parent). Restrictive activities are applied only in borderline situations in which parents anticipate that a situation has overwhelmed their children. Nevertheless, discursive activities are used primarily: «If I get the feeling that she has a problem, then we talk about it and think of solutions together» (Judith, parent). In combination with this style of parenting, adolescents exhibit high evaluative media literacy, with an outstanding analytical dimension. The adolescents' ability to distinguish reality from virtuality is remarkably developed, and they can detect self-production easily. What is striking about this is that they do not see it as negative. Indeed, they even adopt this and try to present it in a very positive light. Consequently, aesthetics is most important to them concerning their Instagram content, even more important than authenticity: "On Instagram, I always feel like if I post something, it should be a good post, where I look good» (Bastian, child). This need is strongly connected to adolescents' awareness of risks: They know that once content is posted, they can never erase it from the web. 
«It's not only on Instagram, though, but everywhere if you upload it and everyone can see it. I think also, especially for me, if I want a job someday, then I shouldn't post pictures when I go to a party or something like that because that wouldn't be so well-received somehow» (Nils, child).

According to this awareness adolescents tend to represent themselves in a very positive way, so that their profile won't cause any unforeseen consequences for them in the future. This positive self-presentation might be one reason why many of the adolescents have a public profile, or tend to accept all «following» requests since - in their judgement - no harm can be caused when strangers are able to see their profile.

This type's abilities in the other dimensions of evaluative media literacy are also well-established. Adolescents detect ads very quickly as well, as they have monetary aspects in mind and judge the advertiser's credibility on that. Furthermore, they view hate speech and negative comments on social media as shameful. Consistently, the most important value reflected is respect. Generally, most of the children and parents' values correspond with each other, punctuating the close relationship between them, the parents asserted.

Compared with other media types, social media are of particular importance: «I couldn't do without, then I wouldn't notice anything anymore. So, Instagram is very important to me» (Tina, child). Nevertheless, they can reflect on their own media use critically. Under the precondition of guidance and freedom that parents afforded them, the adolescents have developed high evaluative media literacy, with an outstanding ability to detect self-promotion. In addition, Instagram is very important to them, and sometimes, they even ignore risks that they anticipated to satisfy their own desire for self-presentation.

\section{Type II: Authentic free spirits}

The authentic free spirits live under a rather permissive parenting style, with lower, but still decent, warmth levels compared with Type I and nearly no control at all. However, these youths' evaluative media literacy is still high. Parents sporadically make use of active-discursive or investigative measures whenever they see the need to intervene: «If we feel like it would be nice that the cellphones are put away during dinner, then you could consider saying something. But otherwise they are all grown up and I don't have the impression something is out of control» (Albert, parent). As the parents have high trust in their children and their media-related abilities, they afford their children many freedoms. Moreover, the adolescence phase elicits a laissez faire approach: «l believe that control in this age doesn't have a positive effect» (Anna, parent). Apart from this, many of the parents consider themselves unable to establish rules regarding Instagram, as they lack the required knowledge to deal with 
the platform. Generally, this type has a good, balanced relationship with parents, emphasizing medium to high warmth in the parenting style.

Compared with other types, authentic free spirits consume media less often and also attach a moderate meaning to Instagram: «I know that if I didn't have [the app], I would also be satisfied» (Carsten, parent). Correspondingly, this type's members are best described as passive users: «Most of the time, I only watch the posts of others. [...]. Very rarely, I upload a photo myself, but that's once in a blue moon» (Steffi, child). The striking point about the authentic free spirits is that when they decide to post something, authentic presentation is the principal focus: «The people who are following me are mostly my best friends. Why should I deceive them by pretending something to be nice? Or that something looks especially good, if they know me anyways» (Anton, child)?

This particularity easily can be connected to the strong analytical dimension to which this second type is attributed. Most of the authentic free spirits can distinguish reality from virtuality precisely. Therefore, in almost all cases, they can recognize staging connected to Instagram. However, most importantly, they stand out because they directly link the analytical to the reflexive dimensions, and through this, they go beyond pure perception. Thus, they take a closer look at the intentions behind a post and assess staging in the context of profit-making, fake self-portrayal, and status enhancement as negative. Authentic free spirits mainly are critical about products that influencers advertise and tend not to follow their recommendations. However, half of the members of this type did not detect the ad at first glance. Moreover, they were only partly aware of Internet dangers to which they are exposed on a daily basis. Nevertheless, the authentic free spirits consider Internet anonymity to be highly risky, especially «[...] because many people just write something, what they would never tell others in real life» (Klara, child). This is why those of this type declare kindness as their highest value: «l believe that you should deal with one another in a friendly way» (Klara, child).

Authentic free spirits develop from the influence of high parental warmth and few or no restrictions, and they have high analytical skills that - in connection with the strong reflexive dimension - lead to a fundamental skepticism toward Instagram in general and influencers and their advertised products in particular.

\section{Type III: Hazard-aware poseurs}

Hazard-aware poseurs are the most controlled adolescents in this typology. The type's parenting style is characterized by regulations and restrictions when it comes to media access and use. «No cell phones at the table - that's our rule. At night, it has to be in the kitchen. It doesn't come to the (bed)room to prevent them from beginning to 'gamble' at night» (Thea, parent). This high control comes with moderate 
warmth when referring to juveniles' media use. These parents are very concerned with social media risks in particular, yet they do not understand the importance of it for adolescents, and the potential benefits often are overlooked: «lt's like that ... (this) new media and this influencer, where we as adults know absolutely nothing about, is just normal and that's not my world. That's why l'd limit it» (Beate, parent). Consequently, parents' interest in their children's social media activities is rather low, which leads to a relative lack of warmth in this regard. Investigative measures, which often are utilized, are not meant to satisfy parents' curiosity about their children's activities. However, to ensure their children follow their rules, conformity is of great importance to the adults: «I expect that if I tell her something or ask her, and she gives me an answer, we come to an agreement or I give an order that she adheres to; I don't stay with that» (Beate, parent). If adolescents do not follow the rules, strict consequences occur. "Then I take the device. I restrict the usage,» Beate (parent) said. This parenting style with media usage can be identified as authoritarian. This style has various effects on the relationship between parents and children. It seems, that with more restrictions and regulations, children feel less motivated to discuss their thoughts and concerns with their parents. They become more like an opponent than a confidant. Following this, high control leads to a less trustful relationship.

In addition, hazard-aware poseurs' media use is moderate in terms of evaluative media literacy. The reason for their lower consumption is less about a lack of interest and more about strict rules to follow. If the adolescents get the chance, they widen their media use extensively. If asked, parents claim active mediation is useless: «But then the addiction is always bigger, especially with Instagram. I see that there are messages popping up at one-second intervals» (Ruth, parent). Instagram is very important for most adolescents, and even the few who claim that it is not feel like they must use it to stay up to date: «They all talked about it, how great it is and what is the newest trend. I found it silly because everyone laughed at me because I didn't have Instagram. Yes, I didn't want to download it at first, but then I thought like I don't care. Then I downloaded it» (Nina, child). The high level of appreciation for Instagram is linked to an inability to distinguish real life from the online realm. For these adolescents, it is difficult to recognize staging. Due to this, they develop envy for influencers and other Instagram users, as well as a desire to show the world an equally perfect picture of themselves: «Probably most people post pictures of themselves where they look perfect; mine don't always look that perfect, but you try to make it as perfect as possible» (Bea, child). However, this type has an outstanding ability to detect online risks, an ability related closely to parenting style, which is based on adults' focus on risks. Privacy issues and data security seem most important to these adolescents. In the other dimensions of evaluative media literacy, their abilities are low to moderate. 
This type shows moderate evaluative media literacy compared with the others. They idolize influencers and try to achieve a similarly perfect self-portrayal online. Parents' tight control indicates a strong vigilance toward online risks to their children but this vigilance seems to fuel the high importance that their adolescent children place on social media, as they were never allowed to experience such media themselves and develop evaluative media literacy.

\section{Type IV: Transfigured Imitators}

Transfigured imitators have the lowest media literacy out of all four types. Given the low warmth and lack of control that these youths experience regarding their education, their parents are often described as careless. A certain ignorance often accompanies this low parental involvement: "She goes to school. I hope she goes to school. Afterward, she hopefully does her homework [...]» (Lydia, parent). This sort of parenting style is viewed as negligent in extant literature. The reasons for this apathy usually can be found in difficult parent-child relationships often linked to the adolescent life stage. Particularly stubborn behavior by youths leads to differences of opinion with their parents: «If she has set her mind on a routine or a special date, then she won't deviate a millimeter from that» (Ulrike, parent). Moreover, this unruly behavior results in no restrictions or rules being applied because «her daughter doesn't care what she [the mother] says; that would end up in a serious fight» (Lydia, parent). In the end, this also can affect parents' support and warmth toward their children, as their behavior is just not «family-compatible» (Ulrike, parent). However, if parents make use of education measures, they most likely will apply investigative methods, particularly for their own sake: «[My husband] could even pursue all their chat messages online [...]. Actually, it was just interesting to hear, when he [the son] chatted with girls» (Nora, parent). Finally, a break in the child-parent relationship becomes evident when the youths fail to adopt the values that parents communicate to them: «Back in the days, just looking good wasn't very important. But confidence, career and equality were important» (Lydia, parent). Hannah, the daughter of this interviewed mother, embodies exactly what Lydia distances herself from. She idolizes certain persons on Instagram based on their looks, because «that would also be nice to be as photogenic» (Hannah, child).

The transfigured imitators live up to their own ideals, reflecting superficial striving for perfection, which social media platforms like Instagram promote. Considering that the members of this type use media intensively and place much value on self-portrayal, their low evaluative media literacy leaves them vulnerable to many threats. Particularly because the youths belonging to this cohort struggle to differentiate between virtuality and reality, they are prone to becoming stuck in an alternative reality that Instagram creates. To approach this ideal of a perfect world, they 
first search for inspiration on the platform, then adapt strategies of representation that they see influencers use: «If I know a person whose feed I like, then I get inspired by that. Hence, I look, how it looks like on her account, then I think if it would also fit for me» (Paula, child). By this, an unrealistic perspective on the world is fostered because for the adolescent, the virtual world functions as a fundamental measuring tool that drives actions. Furthermore, the blurry line between virtuality and reality leads to dangers from Internet use being ignored and privacy becoming a secondary matter. Accordingly, Paula (child) said she also has posted photos of herself in a bikini because «bikinis are meant to be seen in.» Given the struggles that youths have distinguishing real from virtual worlds, they also do not understand the circumstances surrounding product placement. If the reflexive dimension is not notably strong, product placement stimulates relevant buying impulses: «If I like it and if I have enough money to buy it - because I'm rather following people in the high-end section» (Felix, child). Obviously, if intentions are not being detected, it is hard to make a differentiated assessment of the advertised product.

Under the terms of low warmth and low to no control, transfigured imitators have relatively low media literacy compared with other types. The lack of evaluative media literacy can take on an undesirable dynamic of its own if media use and striving for perfection are not regulated in some way.

\section{Discussion}

Results show the relevance of parenting styles in their children's evaluative media literacy. It becomes clear that first, the two criteria of warmth and control exert a decisive influence on adolescents' evaluative media literacy, and second, that adolescents differ in terms of their media literacy depending on parenting style concerning media. Table 2 provides an overview: 


\begin{tabular}{|l|l|l|l|l|l|}
\hline \multicolumn{2}{|l|}{ Type characteristics } & $\begin{array}{l}\text { Type I: } \\
\text { Reflected } \\
\text { self-presen- } \\
\text { ters }\end{array}$ & $\begin{array}{l}\text { Type II: } \\
\text { Authentic } \\
\text { free spirits }\end{array}$ & $\begin{array}{l}\text { Type III: } \\
\text { Hazard-awa- } \\
\text { re poseurs }\end{array}$ & $\begin{array}{l}\text { Type IV: } \\
\text { Transfigured } \\
\text { imitators }\end{array}$ \\
\hline Attributes & Warmth & High & Medium to high & Medium & Low \\
\cline { 2 - 6 } & Control & Low to medium & Low to none & High & Low to none \\
\cline { 2 - 6 } Parenting & Measures & $\begin{array}{l}\text { Strongly active- } \\
\text { discursive, } \\
\text { sometimes } \\
\text { investigative }\end{array}$ & $\begin{array}{l}\text { To some extent } \\
\text { active-discur- } \\
\text { sive, to some } \\
\text { extent investi- } \\
\text { gative }\end{array}$ & $\begin{array}{l}\text { Extremely re- } \\
\text { strictive and } \\
\text { investigative, } \\
\text { seldom active }\end{array}$ & Hardly used \\
\hline $\begin{array}{l}\text { Evaluative media lite- } \\
\text { racy } \\
\text { Strength }\end{array}$ & $\begin{array}{l}\text { Very high } \\
\text { recognition of } \\
\text { opportunities } \\
\text { and risks \& } \\
\text { reflection of } \\
\text { personal media } \\
\text { use }\end{array}$ & $\begin{array}{l}\text { High } \\
\text { distinguishing } \\
\text { virtuality and } \\
\text { reality }\end{array}$ & $\begin{array}{l}\text { Medium } \\
\text { recognition of } \\
\text { risks }\end{array}$ & $\begin{array}{l}\text { Low } \\
\text { none }\end{array}$ & \\
\hline
\end{tabular}

Tab. 2.: Typology of adolescents' evaluative media literacy depending on parenting style.

The described findings indicate that warmth in terms of media education strongly benefits adolescents' evaluative media literacy. The higher the warmth, the higher their media literacy. One of the supposed factors is that warmth comes from parents' high sensitivity to their children's abilities and needs. Through active-discursive mediation, adults create and improve that sensitivity so that parenting styles can be adjusted individually. According to extant studies, an individual parenting style is positively related to high social abilities and high independence (Belsky 1984). Our findings underline this, given that adolescents who experienced a warmer parenting are less likely to imitate influencers or follow their recommendations. Furthermore, these youths tend to have higher social abilities, which shows through the high importance of respect and affability toward juveniles.

Another factor might be that warmth seems to create a positive parent-child relationship, which is characterized by mutual trust. This allows for open discussions, which again enable parents to support juveniles in superior ways. With a less authoritarian structure, parents become more like confidants, making it easier for their children to accept parental advice. This kind of supportive parenting has been proven to exert a positive effect on children's development in a wider context, but when applied to media literacy, our results support this theory (Weber 2015). Although warmth exerts an undeniably positive impact on evaluative media literacy, when adolescents grow up, this warmth needs to be combined with freedom progressively, or else their development might be suppressed in terms of autonomy. Hence, the 
perfect environment for development of evaluative media literacy can be provided through a parenting style that comprises high warmth, but still provides enough latitude for children to develop individually.

Based on the typology, we state that evaluative media literacy decreases with ascending control. Simultaneously non-existent control shows the same effect. Reasons for this can be found in various contexts. One aspect might be that with more restrictions and regulations, parents are less likely to be confidants for children, providing advice and help. Consequently, it becomes more difficult for parents to provide guidance. If no control, for example in terms of regulations exists to the contrary, the adolescents could feel abandoned by their parents and will not turn to them likewise. Furthermore, if parents mostly utilize restrictive measures, children's potential for self-socialization is reduced. During adolescence, children should experiment in a sheltered surrounding to learn how to be a responsible member of society. Consequently, the grade of external control should decrease steadily while the grade of individual responsibility should rise until the juveniles are fully independent. Without that, children cannot tap into their full potential for self-socialization, which leads to lower-level abilities compared with their contemporaries, who can improve theirs through constant trial and error, which is an important factor in developing media literacy, not only in the context of self-socialization, but also for evaluating and classifying media content. If, for example, youths already tried to use certain strategies of self-portrayal themselves, these strategies might get easier to detect, and more important, the ability to evaluate them will be developed. In this way, juveniles will gain a more realistic perspective on content and improve their analytical abilities to prevent idealization of media offers.

Furthermore, a relationship appears to exist between the high value of media to youths and high control, constituted through restrictive measures by parents. A lack of knowledge about media leads to more curiosity about it, especially in this life stage, when restrictions only seem to increase attraction, as well as elicit resistance. During this phase of life, adolescents are likely to ignore rules and restrictions, and even break them on purpose. Accordingly, parents must pay attention and avoid turning their list of limitations into a hit list (Süss 2004). And yet, this life stage may explain why adolescents still need a certain amount of control and restrictions to create supporting circumstances that help develop their evaluative media literacy. To accomplish developmental tasks, juveniles still need their parents' guidance for orientation and support, especially in the tangle of media offers. Therefore, parents' task is to create a supportive, balanced environment through steady adaptation of control over adolescents' abilities and needs, so that they have the freedom they need to master self-socialization, particularly in terms of media socialization. 


\section{References}

Albert, Mathias, Klaus Hurrelmann, Gudrun Quenzel und TNS Infratest Sozialforschung. 2015. Jugend 2015. 17. Shell Jugendstudie. Frankfurt: Fischer Taschenbuch Verlag.

Arnett, Jeffrey Jensen. 1995a. «Adolescents' Use of Media for Self-Socialization.» Journal of Youth and Adolescence 24 (5): 519-533.

Arnett, Jeffrey Jensen. 1995b. «Broad and Narrow Socialization: The Family in the Context of a Cultural Theory.» Journal of Marriage and the Family 57 (3), 617-628.

Arnett, Jeffrey Jensen. 2007. «Socialization in emerging adulthood.»In Socialization. Theory and research, ed. by John E. Grusec und Paul D. Hastings, 208-231. New York: The Guilford Press.

Aßmann, Stefanie and Stephan Röbbeln. 2013. Social Media für Unternehmen - Das Praxisbuch für KMU. 1. Aufl. Bonn: Galileo Computing.

Aufenanger, Stefan. 2006. Medienkritik. «Alte und neue Medien unter der Lupe.» Computer + Unterricht 16 (64): 6-9.

Bachmair, Ben. 2006. «Media socialization and the culturally dominant mode of representation - On the way from the coherent media to semiotic spaces, the example of Popstars». Medienpädagogik (1): 1-36. https://doi.org/10.21240/mpaed/00/2006.06.07.X.

Belsky, Jay. 1984. «The determinants of parenting: A process model». Child Development 55 (1): 83-96. https://doi.org/10.2307/1129836.

Blum-Ross, Alicia, Donoso, Veronica, Dinh, Thuy, Mascheroni, Giovanna, O'Neill, Brian, Riesmeyer, Claudia, and Stoilova, Maria. 2018. Looking forward: Technological and social change in the lives of European children and young people. Report for the ICT Coalition for Children Online. Brussels: ICT Coalition.

Clark, Lynn. 2011. «Parental Mediation Theory for the Digital Age.» Communication Theory 21 (4): 323-343. https://doi.org/10.1111/j.1468-2885.2011.01391.x.

Faßmann, Manuel and Christoph Moss. 2016. Instagram als Marketing-Kanal. Die Positionierung ausgewählter Social-Media-Plattformen. Wiesbaden: VS.

Gentile, Douglas A., Amy I. Nathanson, Eric E. Rasmussen, Rachel A. Reimer and David A. Walsh. 2012. "Do you see what I see? Parent and child reports of parental monitoring of media.» Family Relations 61 (3): 470-487.

Groeben, Norbert. 2004. «Medienkompetenz.» In Lehrbuch der Medienpsychologie, ed. by Roland Mangold, Peter Vorderer und Gary Bente, 27-49. Göttingen: Hogrefe.

Grusec, Joan E. 2002. «Parental socialization and children's acquisition of values.» In Handbook of parenting, ed, by Marc Bornstein, 143-168. Mahwah: Erlbaum.

Gugel, Günther, Nadine Ritzi and Amos Heuss. 2013. Didaktisches Handbuch. Werte vermitteln - Werte leben. Tübingen: Berghof Foundation.

Havighurst, Robert J. 1972. Developmental tasks and education. New York: Longman.

Hurrelmann, Klaus. 1990. «Parents, peers, teachers, and other significant partners in adolescence.» International Journal of Adolescence and Youth, 2: 211-236. 
Hurrelmann, Klaus and Ullrich Bauer. 2015. «Das Modell des produktiv realitätsverarbeitenden Subjekts.» In Handbuch Sozialisationsforschung, ed. by Klaus Hurrelmann, Ullrich Bauer, Matthias Grundmann and Sabine Walper, 144-161. Weinheim u. Basel: Beltz.

Hurrelmann, Klaus and Ullrich Bauer. 2018. Socialisation During the Life Course. Oxon: Routledge.

JIM (2018). JIM-Studie 2018. Jugend, Information, Medien. Elektronisches Dokument: https:// www.mpfs.de/fileadmin/files/Studien/JIM/2018/Studie/JIM_2018_Gesamt.pdf (7.2.2019).

Jiow, Hee Jhee, Sun Sun Lim and Julian Lin. 2017. «Level Up! Refreshing Parental Mediation Theory for Our Digital Media Landscape.» Communication Theory 27 (3): 309-328. https:// doi.org/10.1111/comt.12109.

Keuneke, Susanne. 2017. "Qualitatives Interview.» In Qualitative Medienforschung. Ein Handbuch, ed, by Lothar Mikos and Claudia Wegener, 302-312. Konstanz u. München: UVK.

Kluge, Susann. 2000. «Empirisch begründete Typenbildung in der qualitativen Sozialforschung.» Forum Qualitative Sozialforschung / Forum: Qualitative Social Research 1 (1): Art. 14. http://nbn-resolving.de/urn:nbn:de:0114-fqs0001145.

Lampert, Claudia. 2006. «Medienkompetenz.» In Medien von A bis Z, ed. by Hans-Bredow-Institut, 216-218. Wiesbaden: VS.

Lee, Eunji, Lee, Jung-Ah, Moon, Jang Ho, and Sung, Yongjun. 2015. Pictures speak louder than words. Motivations for using instagram. Cyberpsychology, Behavior and Social Networking, 18(9). https://doi.org/10.1089/cyber.2015.0157.

Lemish, Dafna. 2015. Children and media. A global perspective. Malden: Wiley.

Livingstone, Sonia, Haddon, Leslie and Görzig, Anke. 2012. Children, risk and safety on the internet: research and policy challenges in comparative perspective. Policy Press, Bristol.

Lüscher, Kurt and Ludwig Liegle. 2015. «Das Modell „Generative Sozialisation“.»In Handbuch Sozialisationsforschung, ed. by Klaus Hurrelmann, Ullrich Bauer, Matthias Grundmann and Sabine Walper, 281-301. Weinheim u. Basel: Beltz.

Maccoby, Eleanor Emmons and John A. Martin. 1983. «Socialization in the context of the family: Parent-child interaction.» In Handbook of child psychology, ed. by Paul H. Mussen, 1-101. New York: Wiley.

Mares, Marie-Louise, Laura Stephenson, Nicole Martins and Amy I. Nathanson. 2018. "A house divided: Parental disparity and conflict over media rules predict children's outcomes.» Computers in Human Behavior 81: 177-188. https://doi.org/10.1016/j.chb.2017.12.009.

Mendoza, Kelly. 2009. «Surveying parental mediation: Connections, challenges and questions for media literacy.» Journal of Media Literacy Education 1 (1): 28-41.

Meyen, Michael, Löblich, Maria, Pfaff-Rüdiger, Senta, and Riesmeyer, Claudia. 2019. Qualitative Forschung in der Kommunikationswissenschaft. Wiesbaden. VS.

Nathanson, Amy I. 1999. «Identifying and explaining the relationship between parental mediation and children's aggression.» Communication Research 26 (6): 124-143.

Nathanson, Amy I. 2001. "Parent and child perspectives on the presence and meaning of parental television mediation.» Journal of Broadcasting and Electronic Media 45 (2): 201-220. 
Nathanson, Amy I. 2004. "Factual and evaluative approaches to modifying children's responses to violent television.» Journal of Communication 54 (2): 321-336.

Nathanson, Amy I. 2010. «Using television mediation to stimulate nontraditional gender roles among Caucasian and African American children in the US.» Journal of Children and Media 4 (2): 174-190.

Palfrey, John and Urs Gasser. 2008. Generation Internet. Die Digital Natives. München: Hanser.

Peterson, Gary W. and Della Hann. 1999. "Socializing Children and Parents in Families.» In Handbook of Marriage and the Family, ed. by Marvin B. Sussman, Suzanne K. Steinmetz and Gary W. Peterson, 327- 370. New York: Plenum Press.

Potter, W. James. 2010. «The State of Media Literacy.» Journal of Broadcasting \& Electronic Media 54 (4): 675-696. https://doi.org/10.1080/08838151.2011.521462.

Potter, James. 2013. Media Literacy. London: Sage.

Rozendaal, Esther, Matthew A. Lapierre, Eva A. van Reijmersdal and Moniek Buijzen. 2011. «Reconsidering Advertising Literacy as a Defense Against Advertising Effects.» Media Psychology 14 (4): 333-354. https://doi.org/10.1080/15213269.2011.620540.

Schorb, Bernd. 2005. «Medienkompetenz.»In Grundbegriffe Medienpädagogik, ed. by Jürgen Hüther und Bernd Schorb, 257-262. München: kopaed.

Seel, Norbert M. and Ulrike Hanke. 2015. Erziehungswissenschaft. Berlin u. Heidelberg: VS. https://doi.org/10.1007/978-3-642-55206-9.

Sheldon, Pavica and Bryant, Katherine. 2016. Instagram: Motives for its use and relationship to narcissism and con-textual age. Computers in Human Behavior, 58, 89-97. https://doi. org/10.1016/j.chb.2015.12.059.

Sowka, Alexandra, Christoph Klimmt, Dorothee Hefner, Fenja Mergel and Daniel Possler. 2015. «Die Messung von Medienkompetenz.» Medien \& Kommunikationswissenschaft 63 (1): 62 82. https://doi.org/10.5771/1615-634x-2015-1-62.

Süss, Daniel. 2004. Mediensozialisation von Heranwachsenden. Dimensionen - Konstanten Wandel. Wiesbaden: VS.

Süss, Daniel. 2010. «Mediensozialisation zwischen gesellschaftlicher Entwicklung und Identitätskonstruktion.» In Mediensozialisationstheorien. Modelle und Ansätze in der Diskussion, ed. by Dagmar Hoffmann and Lothar Mikos, 109-130. Wiesbaden: VS.

Treumann, Klaus Peter, Dorothee M. Meister, Uwe Sander, Eckhard Burkatzki, Jörg Hagedorn, Manuela Kämmerer, Mareike Strotmann and Claudia Wegener. 2007. Medienhandeln Jugendlicher. Mediennutzung und Medienkompetenz. Bielefelder Medienkompetenzmodell. Wiesbaden: VS.

Valkenburg, Patti M., Marina Krcmar, Allerd L. Peeters, and Nies M. Marseille. 1999. «Developing a scale to assess three styles of television mediation: Instructive mediation, restrictive mediation, and social coviewing." Journal of Broadcasting and Electronic Media 43 (1): 52-67.

Vogl, Susanne. 2012. Alter und Methode. Ein Vergleich telefonischer und persönlicher Leitfadeninterviews mit Kindern. Wiesbaden: VS. 
Vorderer, Peter, Dorothee Hefner, Leonard Reinecke and Christoph Klimmt. 2017. Permanently online, permanently connected. New York: Routledge.

Wagner, Ulrike. 2011. Medienhandeln, Medienkonvergenz und Sozialisation. Empirische Befunde und gesellschaftswissenschaftliche Perspektiven. München: kopaed.

Wagner, Ulrike. 2013a. «Ein souveränes Leben mit Medien gestalten - Normative Perspektiven medienpädagogischer Forschung.» In Normativität in der Kommunikationswissenschaft, ed. by Matthias Karmasin, Matthias Rath and Barbara Thomaß, 267-288. Wiesbaden: VS.

Wagner, Ulrike, Christa Gebel and Claudia Lampert. 2013b. Zwischen Anspruch und Alltagsbewältigung: Medienerziehung in der Familie. Berlin: Vistas.

Wagner, Ulrike and Christa Gebel. 2014. «Internetgebrauch für gesellschaftlich relevante Information und partizipative Aktivitäten.» In Jugendliche und die Aneignung politischer Information in Online-Medien, ed. by Ulrike Wagner and Christa Gebel, 10-13. Wiesbaden: VS.

Walper, Sabine, Alexandra Langmeyer and Eva-Verena Wendt. 2015. «Sozialisation in der Familie.» In Handbuch Sozialisationsforschung, ed. by Klaus Hurrelmann, Ullrich Bauer, Matthias Grundmann and Sabine Walper, 364-392. Weinheim u. Basel: Beltz.

Warren, Ron. 2001. «In words and deeds: Parental involvement and mediation of children's television viewing.» Journal of Family Communication 1 (4): 211-231.

Weber, Christoph. 2015. Elterliche Erziehung und externalisierende Verhaltensprobleme von Kindern. Linz: VS. 